\title{
Hemşirelik Son Sınıf Öğrencilerinin Mezuniyet Sonrası Psikiyatri Kliniğinde Çalışmaya İlişkin Görüșleri: Nitel Bir Çalıșma
}

Views Of The Senior Nursing Students About Working At A Psychiatry Clinic After Graduation: A Qualitative Study

\section{Sevda UZUN ${ }^{1}$, Sat1 DEMII ${ }^{2}$}

\section{ÖZ}

$\mathrm{Bu}$ araștırmanın amacı hemșirelik son sınıf öğrencilerinin mezuniyetten sonra psikiyatri kliniğinde çalışmaya yönelik görüşlerinin belirlenmesidir.

Çalışmada nitel araştırma modeli kapsamında fenomenoloji deseni kullanılmıştır. Çalışmaya 23 hemşirelik son sınıf öğrencisi katılmıştır. Araştırma kapsamında veri toplamak için araştırmacılar tarafından geliştirilen öğrencilerin demografik özelliklerini içeren soru formu ve yarı yapılandırılmış görüşme formu kullanılmıştır.

Öğrencilerin yaş ortalaması $21,5 \pm 0,51$ 'olup $\% 71,7$ 'sinin hemşirelik mesleğini isteyerek seçtiği, $\% 95,7$ 'sinin hemşirelik mesleğini seçmiş olmaktan memnun olduğu belirlenmiştir. Yapılan analizler sonucunda elde edilen kategoriler; ruhsal hastalık algıs1, ruhsal hastalığı olan bireye ilişkin görüşler, branş olarak psikiyatri hemşireliği ile ilgili görüşler ve psikiyatri kliniğinde çalışma ile ilgili görüşlerdir. Çalışmaya katılan öğrencilerin yarıdan fazlası psikiyatri hemșireliğini özel, doyum veren bir alan olarak gördükleri ve ruhsal hastalığa sahip bireylere yardım etmek istedikleri için psikiyatride çalışabileceklerini öğrencilerin bir kısmının ise bu bireylere ilişkin korku/anksiyete hissettikleri, etkilenebileceklerini ve iletişim kuramayacaklarını düşündükleri için mezuniyet sonrası psikiyatri kliniğinde çalışamayacaklarını ifade etmişlerdir.

Araştırma psikiyatri kliniğinde çalışmayı isteyen öğrencilerin çoğunlukta olduğunu, öğrencilerin bir kısmının ise anksiyete/korku yaşadığını; hemşirelik lisans programındaki ruh sağlığı ve hastalıkları hemşireliği dersinin öğrencilerin ruhsal hastalığa sahip bireylere ilişkin hissedilen korku/anksiyete ile baş etmeyi destekleme ve stigmanın kırılması yönünde planlanması gerektiğini göstermektedir.

Anahtar Kelimeler: Hemşirelik, Psikiyatri Kliniği, Öğrenci

\section{ABSTRACT}

The research was carried out to determine the views of senior nursing students about working at a psychiatric clinic after graduation.

The research has a phenomenological design, one of the qualitative research models. 23 nursing senior students were involved in the study. A questionnaire including the demographic characteristics of the students and a semi-structured interview form were developed by the researchers to collect the data.

The results demonstrated that the mean age of the students was $21.5 \pm 0.51,71.7 \%$ chose the nursing profession voluntarily, and $95.7 \%$ were pleased to choose the nursing profession. The categories that emerged as a result of the analysis were the perception of mental diseases, views about an individual with a mental illness, views about psychiatry nursing as a profession, and views about working at a psychiatry clinic.

More than half of the students expressed that they could work at a psychiatry clinic after graduation because they considered psychiatry nursing as a special and satisfying field and wanted to help individuals with mental illnesses. However, some of them stated that they could not work at a psychiatry clinic as they felt fear/anxiety about these individuals, might be affected by this situation, and could not communicate with them.

The majority of the students wanted to work at a psychiatry clinic, but some of them experienced anxiety/fear. Therefore, the study demonstrated that mental health and disease nursing course in nursing undergraduate program should be planned to support students to cope with their fear/anxiety towards the individuals with mental illness and to break the stigma.

Keywords: Nursing, Psychiatry Clinic, Student

\footnotetext{
${ }^{1}$ Arş. Gör. Sevda UZUN ${ }^{1}$, Psikiyatri Hemşireliği, Gümüşhane Üniversitesi, Sağlık Bilimleri Fakültesi, Hemşirelik Bölümü, sevdauzun50@gmail.com, ORCID: : 0000-0002-5954-717X

${ }^{2}$ Doç. Dr. Satı DEMİR, Psikiyatri Hemșireliği, Gazi Üniversitesi, Sağlık Bilimleri Fakültesi, Hemșirelik Bölümü, satidemir2013@gmail.com, ORCID: :0000-0003-4232-8891 
Hemşirelik, hasta ile etkileşimler sonucunda ihtiyaçların karşılandığı ve problemlerin çözüldüğü ve değişimlerin yaşandığı dinamik bir süreci ifade etmektedir. ${ }^{1}$ Hemşirelerin rollerindeki değişimlerle birlikte eğitim ve uygulama alanında gelişmeler yaşanmış ve uzmanlık alanları ortaya çıkmıştır. $\mathrm{Bu}$ uzmanlık alanlarından birisi de psikiyatri hemşireliğidir. ${ }^{2}$

Ruh sağlığı ve hastalıkları hemşireliği; hemşirenin bilgisini, deneyimini, becerisini, biyolojik ve sosyal bilim verilerini, etkili kullanabilen bilim ve sanattan oluşan bir sağlık disiplinidir. ${ }^{3}$

Lisans eğitiminin birincil amacı her bir öğrencinin mezun olduktan sonra sağlık sektörünün farklı alanlarında profesyonel hemşire olarak çalışmaya hazır duruma gelmesidir. ${ }^{4}$ Eğitsel hazırlığın boyutları arasında ruh sağlığı ve hastalıkları hemşireliği yer almaktadır. Sağlığın fiziksel, psikososyal ve emosyonel yönlerinin olması hemșirelik temel eğitiminde bu alanın önemini vurgulamaktadır.

Ruh sağlığı ve hastalıkları hemșireliği eğitimi; ruh sağlı $\breve{g}_{1}$ ve hastalıkları hemşireliğinin temel ilke, kavram, işlev ve sürecini inceleyerek bunları bireyin ve toplumun ruh sağlığını koruma, geliştirme ve tedavi sürecinde etkin biçimde kullanımını sağlamayı amaçlar. ${ }^{3}$ Bütün bu uygulamaların özünde hemşirelik öğrencilerinden hasta ve danıșanlarını terapötik iletișim tekniklerini kullanarak bütüncül bakım felsefesi temelinde, ruh sağlığı ve hastalıkları hemşireliğine özgü bilgiler doğrultusunda değerlendirme yapması beklenmektedir. ${ }^{3,5}$

Ruh sağlığı ve hastalıkları hemşireliğinde kullanılan bilgi ve becerilerin öğrenciye kazandırılmasında eğitim sürecinin klinik aşaması oldukça önemlidir ve öğrencinin profesyonel kimlik gelişimi için kazanabilmesi için gereklidir. $^{6}$

Ruh sağlığı ve hastalıkları hemşireliği eğitiminin klinik uygulamasında öğrencilerden kendi duygu ve düşüncelerinin farkında olarak bireyi ruhsal olarak değerlendirme ve görüşme yapabilme, bakım verebilme ve terapötik iletișim kurabilme gibi yeterlilikler beklenmektedir. ${ }^{3} \mathrm{Bu}$ süreç, oldukça önemlidir fakat öğrenciler uygulama alanlarında pek çok zorluklarla da karşı karşıya kalmaktadırlar. $^{7}$

Literatürde ruh sağlığı ve hastalıkları hemşireliği dersinin öğrenciler üzerindeki etkilerini inceleyen çalışmalar bulunmakla birlikte öğrencilerin mezuniyet sonrası psikiyatri kliniğinde çalışmaya ilişkin görüşlerini ortaya koyan nitel bir çalışmaya ulaşılamamıştır. ${ }^{5,8,9}$

Öğrencilerin psikiyatri kliniğinde çalışmaya yönelik görüşlerinin belirlenmesi, ögrencilerde mezuniyet sonrası ruhsal hastalık ve ruhsal hastalığı olan bireylere bakım vermeye yönelik olumlu alg1 geliştirmenin yollarına ilişkin eğitimcilere katkı sağlayabilir. $\mathrm{Bu}$ nedenle planlanan çalışmada ruh sağlığı ve hastalıkları hemşireliği dersini alan hemşirelik son sınıf öğrencilerinin, mezuniyetten sonra psikiyatri kliniğinde çalışmaya yönelik görüşlerinin belirlenmesi amaçlanmıştır.

\section{MATERYAL VE METOT}

\section{Araştırmanın Amacı ve Tipi:}

Araştırma hemşirelik son sinıf öğrencilerinin mezuniyet sonrası psikiyatri kliniğinde çalışmaya ilișkin görüşlerini belirlenmek amacıyla nitel bir çalıșma olarak yapılmıştır.

\section{Çalıșma Grubu}

Gümüşhane Üniversitesi Sağlık Bilimleri Fakültesi Hemşirelik bölümünün 2019-2020 eğitim- öğretim y1lı güz dönemindeki son sınıf (4. Sınıf) öğrencileri çalıșmanın evrenini oluşturmaktadır. Son sınıfa devam eden toplam 96 hemşirelik öğrencisi bulunmaktadır. Öğrenciler son sınıf güz 
döneminde meslek derslerinden ruh sağlığ ve hastalıkları hemşireliği dersini almaktadır. $\mathrm{Bu}$ ders saati bir dönemde toplam 84 saatlik teorik ve 08-16.00 saatleri arasında yürütülen sekiz günlük klinik uygulamadan oluşmaktadır. Öğrencilerin teorik dersin \%70'ine ve klinik uygulamanın ise tamamına devam zorunluluğu bulunmaktadır. Dönemdeki teorik derslerin tamamlanmasının arkasından klinik uygulama başlamaktadır. Klinik uygulama, Devlet Hastanesi, Toplum Ruh Sağlığ Merkezi ve Özel Eğitim Merkezi'nde yürütülmektedir. Öğrenciler bu merkezlerde öğretim elemanı ve merkez çalışanları rehberliğinde ruhsal hastalık tanısı almış olan bireylerle çalışmayı deneyimlemektedir. Çalışmada dahil edilme kriterleri; çalışmaya katılımda gönüllü olma, psikiyatri hemşireliği dersinin teorik ve klinik uygulamasının devam zorunluluğunu sağlamış olma, dışlama kriterleri ise; dersi tekrar alıyor olma ve ruhsal hastalık tanısı varlığ 1 şeklinde belirlenmiştir. Çalışmaya gönüllü olarak katılmayı kabul eden 23 hemşirelik son sınıf öğrencisi katılmıştır. İçleme kriterlerini karşılayan öğrencilerle görüşmelere veriler doygunluğa ulaşana kadar devam edilmiştir. Veriler tekrarlanmaya başladığında ve yeni veri elde edilemediğinde görüşmeler sonlandırılmıştır. $\mathrm{Bu}$ şekilde çalışma 23 katılımeı ile tamamlanmıştır.

\section{Veri Toplama Araçları}

Araştırmanın verileri "Katılımcı bilgi formu" ve "Yarı yapılandırılmış görüşme formu" ile toplanmıştır.

\section{Katılımcı Bilgi Formu}

Araştırmacılar tarafından hazırlanan bu formda yaş, cinsiyet, medeni durum, hemşirelik mesleğini tercih etme durumu, meslek tercihinden memnuniyet durumu ve ailede ruhsal hastalik durumu ile ilgili alt1 soru yer almaktadir.

\section{Yarı Yapılandırılmış Görüşme Formu}

$\mathrm{Bu}$ form hemşirelik son sınıf öğrencilerinin psikiyatri kliniğinde çalışmaya ilişkin görüşlerinin belirlenmesi amacıyla araştırmacılar tarafindan uzman görüşü alınarak oluşturulmuştur. Derinlemesine bireysel görüşme yapılırken bu form kullanılmıştır. Görüşme formu "giriş bölümü, araştırma-görüşme soruları ve kapanış" bölümlerinden oluşmaktadır. ${ }^{10}$ Giriş bölümü görüşmecinin kendini tanıtması, görüşmenin amacı ve özelliklerini açılamasını içermektedir. Görüşme formunda yer alan sorular şunlardır;

1. "Ruhsal hastalık" kavramı sizin için ne ifade ediyor? (Katılımc1 cevap verdikten sonra; "Ruhsal hastalığı, fiziksel hastalıkla karşılaştırdığınızda ne söylersiniz? Tedavi edilebilir mi? Bireyler üzerindeki etkileri nelerdir?" gibi sorular sorularak katılımcı anlatımlarını derinleştirmeye teşvik edilir.)

2. Ruhsal hastalığa sahip bireylerle ilgili düşünceleriniz nelerdir? (Katılımcı cevap verdikten sonra; "Kişilerarası ilişkileri nasıldır? Çevresindeki insanlara karşı davranışları nasıldır? Ruhsal hastalığı olan bireyle aynı ortamda bulunma ile ilgili ne düşünüyorsunuz? Ruhsal hastalığı olan bireyle zaman geçirme/arkadaşlık etme ile ilgili ne düşünüyorsunuz? Açıklar mısınız? Örnek verir misiniz?" gibi ifadelerle katılımcı anlatımlarını derinleştirmeye teşvik edilir.)

3. Meslek olarak psikiyatri hemşireliği ile ilgili ne düşünüyorsunuz? (Ruhsal Hastalığı olan bireye bakım verme ile ilgili ne düşünüyorsunuz? Sizin için olumlu/kolaylaştırıcı yanları nelerdir? Sizin için olumsuz/güçleştirici yanları nelerdir?)

4. Mezuniyetten sonra psikiyatri kliniğinde çalışma ile ilgili ne düşünüyorsunuz? (Çalışmak isterim ya da istemem şeklindeki cevaplardan sonra; "Çalışmayı isteme nedenleriniz nedir? Çalışmayı istememe nedenleriniz nedir?" soruları ile katılımc1 anlatımlarını derinleştirmeye teşvik edilir.)

Hazırlanan açık uçlu sorulara, alanda uzman iki akademisyenin görüşüne sunularak son hali verilmiştir. Hazırlanan açık uçlu sorulara son hali verildikten sonra iki hemşirelik son sınıf öğrencisiyle pilot 
görüşme yapılmıştır. Pilot uygulama sonucunda görüşme sorularının uygun olduğu sonucuna varılmıştır.

\section{Verilerin Toplanması}

Veriler, yüz yüze görüşme tekniğinin kullanıldığı yarı yapılandırılmış derinlemesine bireysel görüşme ile toplanmıştır. $^{11}$ Görüşmede önceden belirlenmiş sorulardan yola çıkılarak gelen yanıtlara ve görüşmenin akışına bağlı olarak alt sorular sorularak görüşmenin derinliği arttırılmıştır. Derinlemesine yapılan görüşmelerde araştırmacı görüşmenin akışını belirleyebilir, alt sorularla zamandan kazanç sağlayabilir. Ayrıca alt soruların kullanılması, görüşmede esneklik ve karşılıklı etkileşim sağladığı için görüşmenin katılımcı tarafından anket uygulaması gibi algılanmasinı önleyebilmektedir. ${ }^{10}$ Görüşmeler Şubat-Mart 2020 tarihleri arasında Sağlık Bilimleri Fakültesi binasında görüşmenin bölünmeyeceği sessiz bir odada birinci araştırmacı tarafından yapılmıştır. Görüşme süresi ortalama 25-30 dakika sürmüştür. Görüşme sırasında elde edilen verilerin kaydı için ses kayıt cihazı kullanılmıştır. Kapanış bölümünde ise bireye teşekkür edilerek görüşme sonlandırılmıştır.

\section{Araştırmanın Etik Yönü}

Araştırmanın yapılabilmesi için Gümüşhane Üniversitesi Bilimsel Araştırma ve Yayın Etiği Kurulundan (2020/2 sayılı) ve Gümüşhane Üniversitesi Sağlık Bilimleri Fakültesi Dekanlığı'ndan (48231940-619E.8641) izin alınmıştır. Katılımcıların bilgilendirilmesi amaciyla araştırmacılar tarafindan "Gönüllü Bilgilendirilmiş İzin Formu" görüşme öncesinde katılımcılar tarafindan okunup imzalanmıştır. Ses kayıt cihazı kullanılacağı belirtilen metinde, kimliklerin ve ses kaydının gizliliği konusunda güvence verilmiştir. Çalışmada araştırmacılar tarafindan hazırlanan sosyo-demografik özellikleri içeren anket formu ve yarı yapılandırılmış görüşme formu kullanılmıştır. Bulgularda yer alan doğrudan alıntılarda, katılımcılar numaralandırılarak Ö1, Ö2 şeklinde belirtilmiştir.

\section{Verilerin Analizi}

Verilerin değerlendirilmesinde tanımlayıcı analizler (say1, yüzde, ortalama, standart sapma) ile içerik analiz yöntemi (yarı yapılandırılmış görüşme verileri için) kullanılmıştır. İçerik analizinde temelde yapılan işlem, birbirine benzeyen verileri belirli kodlar, kategoriler ve temalar çerçevesinde bir araya getirmek ve bunları okuyucunun anlayabileceği bir biçimde düzenleyip yorumlamaktır. Bu işlem birtakım aşamalardan oluşmaktadır. $\mathrm{Bu}$ çalışmada; kod, kategori ve temaların oluşturulması aşamaları izlenmiştir. ${ }^{12}$ Veri analizinde ilk önce ses kayıt cihazına kaydedilen görüşmeler verilerin doğal haline hiç dokunulmadan bilgisayara aktarılarak ve metnin yanına varsa katılımcıların jestleri, ses tonu değişiklikleri gibi veriler not edilerek kaydedilmiştir. ${ }^{13,14}$ Veriler yazılırken bireylerin isimleri kullanılmamış olup analizde kolaylık sağlaması bakımından görüşme yapılan her birey numaralandırılarak kodlanmıştır (Örneğin Öğrenci 1 için Ö1, Öğrenci 2 için Ö2 gibi). Analize geçmeden önce veriler dikkatlice tekrar okunmuş, araştırma açısından önemli veriler kodlanmış ve uygun kodlar bir araya getirilerek kategoriler oluşturulmuştur. ${ }^{12,14,15}$ Uygun kategorilerin bir araya getirilmesiyle araştırmanın temaları oluşturulmuştur. ${ }^{13,15}$ Son olarak temalar okuyucunun anlayabileceği bir biçimde düzenlenerek yorumlanmıştır. ${ }^{14}$ Araştırmada geçerlik ve güvenirlik için gerekli ölçütler dikkate alınmıştır. Geçerlik, iç ve diş geçerlik; güvenirlik ise, iç ve dış güvenirlik olmak üzere iki bölümden oluşmaktadır. İç geçerlik inandırıcılık, dış geçerlik aktarılabilirlik; iç güvenirlik tutarlılık, dış güvenirlik teyit edebilirlik olarak ele alınmıştır. ${ }^{10,14,15} \mathrm{Bu}$ araştırmanın inandırıcılığını sağlamak amacıyla bütün görüşmeler ses kayıt cihazı ile kayı edilmiş ve beraberinde araştırmacı gözlem notu tutmuştur. Analizler konu ile ilgili eğitimi ve deneyimi olan açık uçlu soruların hazırlanmasında da görüş bildiren iki uzman tarafından değerlendirilmiştir. Bu araştırmada kullanılacak veri toplama araçları, araştırmanın ham verileri, analiz aşamasında yapılacak kodlamalar ve diğer 
tüm materyaller teyit edilebilirlik açısından saklı tutulacaktır.

Öğrencilerin psikiyatri kliniğinde çalıșmaya ilişkin görüşleri dört kategori altında tema ve kodlar şeklinde belirlenmiștir. Kategori, tema ve kodlar daha anlaşılır olması açısından şematize edilmiștir (Şekil 1).

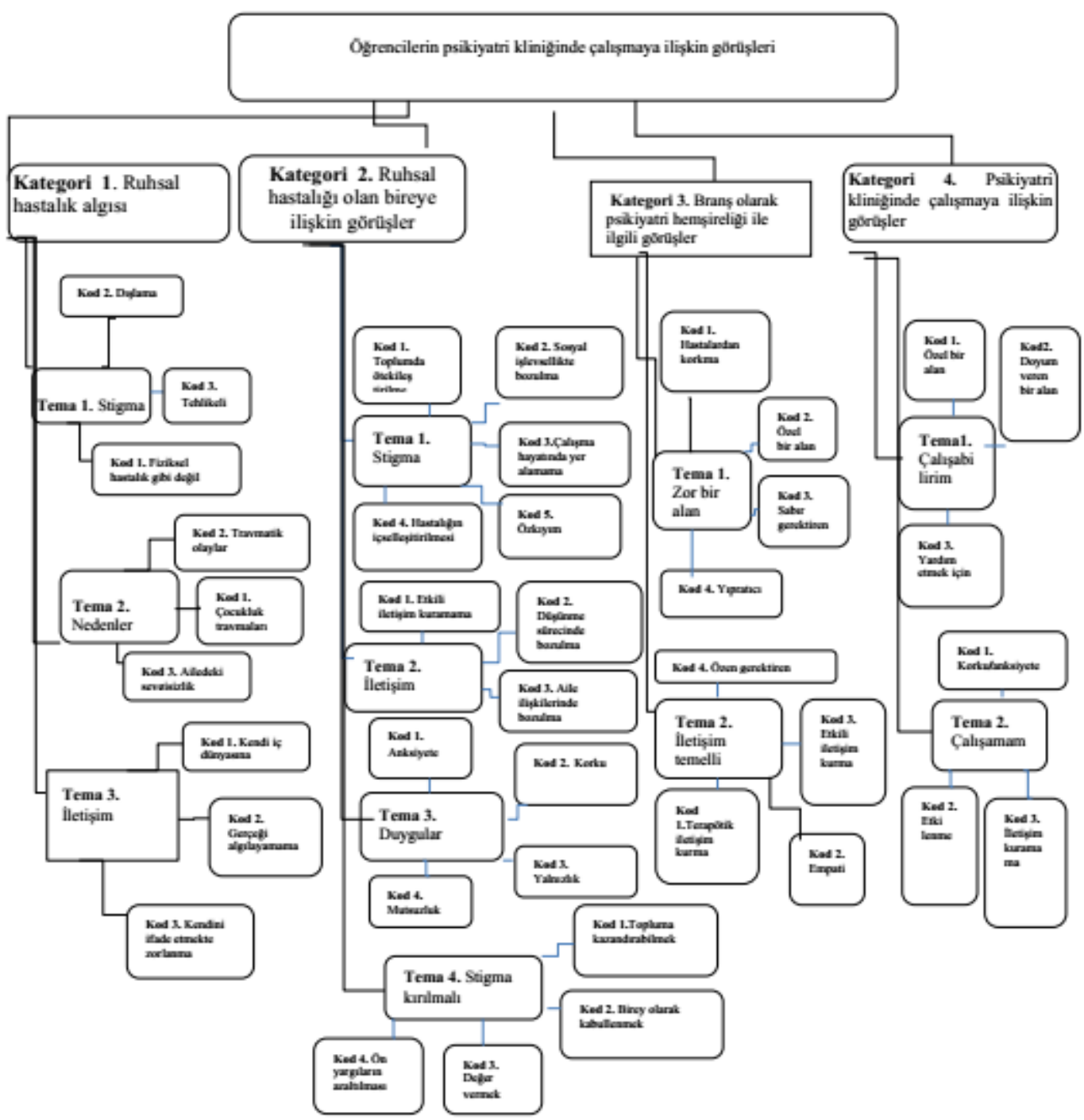

Şekil 1. Yarı Yapılandırılmış Görüş̧meye Ait Kategori ve Şemalar Özeti

\section{Araştırmanın Sınırlııkları}

Araştırmanın sadece bir üniversitenin sağlık bilimleri fakültesi hemşirelik bölümü son sınıf öğrencilerinin görüşlerini içermesi, dolayısıyla toplumun diğer kesimlerinin görüşlerinin yansitılamaması bu araştırmadaki en önemli sınırlılık olarak değerlendirilebilir.

\section{Teșekkür}

Gönüllü katılımlarından dolayı hemșirelik son sınıf öğrencilerine teșekkürü bir borç biliriz. 


\section{BULGULAR VE TARTIŞMA}

Bulgular çalışmaya katılan 23 öğrenci ile yapılan görüşmelerden elde edilmiştir. Öğrencilerin beşi erkek on sekizi kadın ve tamamı bekardır. Yaş ortalaması 21,5 $\pm 0,51$ (min-max=21-22). Öğrencilerin \%71,7'sinin hemşirelik mesleğini isteyerek seçtiği, \%95,7'sinin hemşirelik mesleğini seçmiş olmaktan memnun olduğu, \%21,7'sinin ailesinde ruhsal hastalık tanisı alan bir bireyin olduğu saptanmıştır. Ailedeki ruhsal hastalıklar ise depresyon $(n=3)$, obsesif kompulsif bozukluk $(\mathrm{n}=1)$ ve yaygin anksiyete bozukluğu $(\mathrm{n}=1) \quad$ şeklindedir (Tablo 1).

Tablo 1. Çalışma Grubunun Sosyo-demografik Özellikleri ( $\mathbf{N = 2 3})$

\begin{tabular}{|c|c|c|}
\hline Değişken & n & $\%$ \\
\hline \multicolumn{3}{|l|}{ Yaş } \\
\hline 21 & 11 & 47.8 \\
\hline 22 & 12 & 52.2 \\
\hline \multicolumn{3}{|l|}{ Cinsiyet } \\
\hline Kadın & 18 & 78.3 \\
\hline Erkek & 5 & 21.7 \\
\hline \multicolumn{3}{|l|}{ Medeni Durum } \\
\hline Evli & 0 & 0 \\
\hline Bekar & 23 & 100.0 \\
\hline \multicolumn{3}{|l|}{ Mesleği isteyerek seçme } \\
\hline Evet & 18 & 71.7 \\
\hline Hayır & 5 & 28.3 \\
\hline \multicolumn{3}{|l|}{ Meslekten memnun olma } \\
\hline Evet & 22 & 95.7 \\
\hline Hayır & 1 & 4.3 \\
\hline \multicolumn{3}{|l|}{ Ailede ruhsal hastalık } \\
\hline Var & 5 & 21.7 \\
\hline Yok & 18 & 78.3 \\
\hline \multicolumn{3}{|c|}{$\begin{array}{l}\text { Ailede görülen } \\
\text { tanısı }\end{array}$} \\
\hline Yaygın anksiyete bozukluğu & 1 & 4.3 \\
\hline Obsesif kompulsif bozukluk & 1 & 4.3 \\
\hline Depresyon & 3 & 12.9 \\
\hline Hastalık yok & 18 & 87.5 \\
\hline \multicolumn{3}{|c|}{ Bireyde var olan ruhsal hastalık } \\
\hline Var & 0 & 0 \\
\hline Yok & 23 & 100.0 \\
\hline Toplam & 23 & $\mathbf{1 0 0 . 0}$ \\
\hline
\end{tabular}

Çalışma grubunun sosyo-demografik özelliklerine göre dağılımı Tablo 1'de verilmiştir. Katılımcıların klinik uygulamaya çıkma gün ve saatlerine baktığımızda öğrencilerin hepsi $(n=23)$ Konsültasyon Liyezon hemşireliği kapsamında Gümüşhane
Devlet Hastanesine klinik uygulamaya çıkmaktadır. Fakat şehir ve kurum koşulları (kurumların küçük olması, sınıf mevcudunun fazla olması) nedeniyle her öğrenci her kurumda eșit günlerde uygulama yapamamaktadır. $\mathrm{Bu}$ sebeplerden dolay 1 katılımcılardan 13'ü altı gün Gümüşhane Devlet Hastanesinde, 11'i iki gün Gümüşhane Özel Eğitim Merkezinde, 13 kişide Gümüşhane Toplum Ruh Sağlı̆̆1 Merkezi'nde Ruh Sağlığı ve Hastalıkları Hemşireliği dersi kapsamında uygulama yapmaktadır (Tablo 1).

Tablo 2'de hemşirelik son sinıf öğrencilerinin ruhsal hastalığa yönelik algısını içeren kod ve temalar yer almaktadır.

Tablo 2. Hemşirelik Son Sınıf Öğrencilerinin Ruhsal Hastalığa Yönelik Algısı

\begin{tabular}{|c|c|c|c|}
\hline Tema & Kod & Katılımcılar & $\mathbf{f}$ \\
\hline \multirow[t]{3}{*}{ Stigma } & $\begin{array}{l}\text { Fiziksel } \\
\text { hastalık gibi } \\
\text { değil }\end{array}$ & $\begin{array}{l}\text { Ö1, Ö2, Ö3, } \\
\text { Ö4, Ö7, Ö10, } \\
\text { Ö12, Ö13, } \\
\text { Ö15, Ö16, Ö19, } \\
\text { Ö20 }\end{array}$ & 12 \\
\hline & Dişlama & $\begin{array}{l}\text { Ö13, Ö16, } \\
\text { Ö20, Ö23 }\end{array}$ & 4 \\
\hline & Tehlikeli & $\begin{array}{l}\text { Ö6, Ö14, } \\
\text { Ö15, Ö23 }\end{array}$ & 4 \\
\hline \multirow[t]{3}{*}{ Nedenler } & $\begin{array}{l}\text { Travmatik } \\
\text { olaylar }\end{array}$ & $\begin{array}{l}\text { Ö12, Ö19, } \\
\text { Ö21, Ö22 }\end{array}$ & 4 \\
\hline & $\begin{array}{l}\text { Çocukluk } \\
\text { Travmaları }\end{array}$ & Ö6, Ö12, Ö23 & 3 \\
\hline & $\begin{array}{l}\text { Ailedeki } \\
\text { sevgisizlik }\end{array}$ & Ö11, Ö15 & 2 \\
\hline \multirow[t]{3}{*}{$\begin{array}{l}\text { İletişim } \\
\text { Sorunları }\end{array}$} & $\begin{array}{ll}\text { Kendi } & \text { iç } \\
\text { dünyasına } & \\
\text { cekilme } & \end{array}$ & $\begin{array}{l}\text { Ö13, Ö18, } \\
\text { Ö20 }\end{array}$ & 3 \\
\hline & $\begin{array}{l}\text { Gerçeği } \\
\text { algılaya- } \\
\text { mama }\end{array}$ & Ö1, Ö2, Ö13 & 3 \\
\hline & $\begin{array}{l}\text { Kendini ifade } \\
\text { etmede } \\
\text { zorlanma }\end{array}$ & Ö22 & 1 \\
\hline Toplam & & & 36 \\
\hline
\end{tabular}

\section{Kategori 1. Ruhsal Hastalık Algısı}

\section{Tema 1-Stigma}

Üç alt temadan oluşmaktadır.

\section{-Dışlama}

Öğrenciler ruhsal hastalığa sahip bireyin toplumdan dişlandığını düşünmektedir. Bir öğrenci şu şekilde ifade etmiştir: "Ruhsal hastalık toplumdan soyutlanarak yaşamaktır" 
(Ö16).Diğer bir öğrenci ruhsal hastalığa sahip bireyin yaşadığı stigmayı şu şekilde belirtmiştir."Ruhsal hastalığa sahip bireylerin en çok etkilendiği durumun toplumun onları ötekileştirmesi olduğunu düşünüyorum" (Ö20).

\section{-Tehlikeli}

Geleceğin sağlik profesyonelleri olan hemşirelik öğrencileri ruhsal hastalığa sahip bireylerin tehlikeli olduğunu düşünmektedir. Bir öğrencinin ifadesi "Ruhsal hastalığa sahip bireyleri tehlikeli buluyorum bana saldıracaklarını düşünüyorum ve korkuyorum"dur. (Ö23).

\section{-Fiziksel Hastalık Gibi Değil}

Öğrenciler ruhsal hastalığın fiziksel hastalık gibi olmadığını ruhsal hastalığın etki boyutları, iyileşme süreçleri yönünden farklı olduğunu düşünmektedirler. Aşağıda öğrencilerin ifadelerinden örnekler verilmiştir. "Fiziksel hastalıkla ruhsal hastalığı kıyasladığımda fiziksel hastalığa nazaran ruhsal hastalığın iyileşme dönemi daha uzun süre alır" (Ö20)."Ruhsal hastalık fiziksel hastalık gibi değildir ruhsal hastalıkta fiziksel hastalığa nazaran daha az acı çekilir”(Ö16).“Ruhsal hastalık fiziksel hastalığa nazaran bireye daha çok zarar verir. Fiziksel hastalık laboratuvar bulgularıla saptanabilir ruhsal hastalık laboratuvar bulgularıyla saptanamaz ve Ruhsal hastalıkta fiziksel hastalığa nazaran günlük yaşam daha çok etkilenir" (Ö7). "Fiziksel hastalıkta stigma ruhsal hastalığa nazaran daha azdır, Ruhsal hastalıkta birey yalnızlık yaşar ve hastalığını gizler"(Ö19). "Ruhsal hastalıkta fiziksel hastalığa nazaran daha fazla yardıma ihtiyacı olur bireyin" (Ö3)

\section{Tema 2- Nedenler}

Üç alt temadan oluşmaktadır.

\section{-Çocukluk Travmaları}

Öğrenciler çocukluk travmalarının ruhsal hastalığa neden olacağını düşünmektedir. Bir öğrenci ruhsal hastalığın çocukluk travmasından dolayı olduğunu şu şekilde belirtmiştir. "Ruhsal hastalıklar çocuklukta yaşanan olaylar ve travmalara maruz kalma sonucunda oluşur " (Ö6).

\section{-Travmatik Olaylar}

Öğrenciler yaşanan travmaların ruhsal hastalığa sebep olacağını düşünmektedir. Bir öğrencinin ifadesi "Ruhsal hastalık kişinin yaşadığı travmalar sonucu oluşan hastalıktır" tır. (Ö6). Başka bir öğrenci ruhsal hastalıkların travmatik olaylar sonucu oluştuğunu şöyle belirtmektedir: "Ruhsal hastalıklara sahip bireyleri gördüğümde hep bu insanlar hangi travmatik olayı yaşadı da bu hale geldi diye düşünürüm” (Ö1).“Bireyin yaşadığı bir olay sonucunda bu bir trafik kazası olur ya da yakını kaybetme olur bunun sonucunda yaşadığı ruhsal çökkünlüktür" (Ö19).

\section{Ailedeki Sevgisizlik}

Öğrenciler ruhsal hastalıkların oluşumunda ailedeki sevgisizliğin önemli rol oynadığını ifade etmiştir. Bir öğrenci ruhsal hastalığın sevgisizlikten kaynaklandığını şöyle belirtmiştir: "Ruhsal hastalıkların oluşumunda ailedeki sevgisizlik önemli rol oynar" (Ö11).

\section{Tema 3-İletişim Sorunları}

Üç alt temadan oluşmaktadır.

\section{•Kendi İç Dünyasına Çekilme}

Öğrenciler ruhsal hastalığa sahip bireylerin kendi iç dünyasına çekildiklerini belirtmiştir. Bir öğrenci ruhsal hastalığa sahip bireylerin yaşadıklarını şöyle ifade etmiştir:"Ruhsal hastalığa sahip birey kendi içi dünyasında yaşar ve başkalarıyla ilişki kurmaz" (Ö13). Diğer bir öğrenci ruhsal hastalığa sahip bireylerin kendi iç dünyalarına çekildiklerini ve bu konuda onların bu durumdan kurtulmalarına yardım edilmesi gerektiğini ifade etmiştir. "Ruhsal hastalığa sahip bireyler kendi iç dünyalarına çekilirler ve bu durumda onların yardıma ihtiyacı vardır ve yardım edilmesi gerekir"(Ö18).

\section{•Gerçeği Algılayamama}

Öğrenciler ruhsal hastalığa sahip bireylerin gerçeği algılamakta zorlandıklarını ifade etmiştir. Bir öğrencinin ifadesi "Ruhsal 
hastalığa sahip birey normal insanlar gibi gerçeği algılayamaz normal duygulanım gösteremez" dir. (Ö13).

\section{-Kendini İfade Etmede Zorlanma}

Öğrenciler ruhsal hastalığa sahip bireylerin kendilerini ifade etmekte zorlandıklarını ifade etmiştir. Bir öğrenci şu şekilde belirtmiştir: "Ruhsal hastalığa sahip bireyler iletişim kurmakta zorlanırlar daha doğrusu etkili iletişim kuramazlar. Ruhsal hastalığa sahip bireyler genellikle kısitlı iletişim kurarlar ve çevresiyle çok fazla iletişime geçmezler" (Ö22). Başka bir öğrenci ruhsal hastalığa sahip bireylerin kendini ifade etmekte zorlandığını belirtmiştir. Öğrencinin ifadesi "Ruhsal hastalığa sahip bireyler genellikle toplumdan uzaklaşır ve kısitlı iletişim kurarlar" dır. (Ö15). Tablo 3'de hemşirelik son sinıf öğrencilerinin ruhsal hastalığı olan bireye ilişkin görüşlerine yönelik kod ve temalar yer almaktadır.

Tablo 3. Hemşirelik Son Sınıf Öğrencilerinin Ruhsal Hastalığı Olan Bireye İlişkin Görüşleri

\begin{tabular}{|c|c|c|c|}
\hline Tema & Kod & Katılımcı & $\mathbf{f}$ \\
\hline \multirow[t]{5}{*}{ Stigma } & $\begin{array}{l}\text { Toplumda } \\
\text { ötekileştirilme }\end{array}$ & $\begin{array}{l}\text { Ö1, Ö3, Ö8, } \\
\text { Ö10, Ö11, } \\
\text { Ö12, Ö113, } \\
\text { Ö15, Ö16, } \\
\text { Ö17, Ö20, } \\
\text { Ö22 }\end{array}$ & 12 \\
\hline & $\begin{array}{l}\text { Sosyal işlevsellikte } \\
\text { bozulma }\end{array}$ & $\begin{array}{l}\text { Ö5,Ö7, } \\
\text { Ö8, Ö12 }\end{array}$ & 4 \\
\hline & $\begin{array}{l}\text { Çalışma hayatında yer } \\
\text { alamama }\end{array}$ & $\begin{array}{l}\text { Ö6, } \\
\text { Ö15 }\end{array}$ & 3 \\
\hline & $\begin{array}{l}\text { Hastalığın } \\
\text { içselleştirilmesi }\end{array}$ & $\begin{array}{l}\text { Ö10, } \\
\text { Ö23 }\end{array}$ & 3 \\
\hline & $\begin{array}{l}\text { Öz kiyım } \\
\text { (İntihar ) }\end{array}$ & $\begin{array}{l}\text { Ö20, } \\
\text { Ö23 }\end{array}$ & 3 \\
\hline \multirow[t]{3}{*}{ İletişim } & $\begin{array}{ll}\text { Etkili } & \text { iletişim } \\
\text { kuramama } & \end{array}$ & Ö2, Ö9, Ö22 & 3 \\
\hline & $\begin{array}{l}\text { Düşünme sürecinde } \\
\text { bozulma }\end{array}$ & Ö5 & 1 \\
\hline & $\begin{array}{l}\text { Aile ilişkilerinde } \\
\text { bozulma }\end{array}$ & Ö23 & 1 \\
\hline \multirow[t]{4}{*}{ Duygular } & Anksiyete & $\begin{array}{l}\text { Ö8, Ö9, Ö10, } \\
\text { Ö11 }\end{array}$ & 4 \\
\hline & Mutsuzluk & Ö11, Ö16 & 2 \\
\hline & Yalnızlık & Ö21 & 1 \\
\hline & Öfke & Ö20 & 1 \\
\hline \multirow{5}{*}{$\begin{array}{l}\text { Stigma } \\
\text { kırılmalı }\end{array}$} & Topluma & Ö2, Ö4, & 4 \\
\hline & kazandırabilmek & Ö11, Ö16 & \\
\hline & $\begin{array}{ll}\text { Birey } & \text { olarak } \\
\text { kabullenmek }\end{array}$ & $\begin{array}{l}\text { Ö4, } \\
\text { Ö16 }\end{array}$ & 3 \\
\hline & Değer vermek & Ö11, Ö15 & 2 \\
\hline & $\begin{array}{ll}\text { Ön } & \text { yargiların } \\
\text { azaltılması } & \end{array}$ & Ö11, Ö22 & 2 \\
\hline
\end{tabular}

Kategori 2. "Ruhsal hastalığı olan bireye ilişkin görüşler"

\section{Tema 1- Stigma}

Beş alt temadan oluşmaktadır.

\section{-Toplumda Ötekileștirilme}

Öğrenciler ruhsal hastalığa sahip bireylerin toplumda ötekileştirildiklerini ifade etmişlerdir. Bir öğrencinin ifadesi "Ruhsal hastalığa sahip bireylerin en çok etkilendiği durumun toplumun onları ötekileştirmesi olduğunu düşünüyorum"dur. (Ö20).Başka bir öğrenci ruhsal hastalığa sahip bireylerin toplumda ötekileştirildiğini şu şekilde belirtmiştir: "Ruhsal hastalığa sahip birey kendini toplumdan uzak tutabilir" (Ö12).

\section{-Sosyal İşlevsellikte Bozulma}

Öğrenciler ruhsal hastalığa sahip bireylerin sosyal işlevsellikte bozulma yaşadıklarını belirtmiştir. Bir öğrencinin ifadesi "Ruhsal hastalığa sahip bireylerin sosyal işlevselliği bozulur ve üzerlerinde bir baskı hissederler bu baskı çevre baskısıdır" şeklindedir (Ö7).

\section{-Çalışma Hayatında Yer Alamama}

Öğrenciler ruhsal hastalığa sahip bireylerin çalışma hayatında yer alamadığını belirtmiştir. Bir öğrencinin ruhsal hastalığa sahip bireylerin yaşadıklarını şu şekilde dile getirmiştir.

"Ruhsal hastalığa sahip bireyler hastalıklarından dolayı istedikleri işte çalışamazlar ya da hiçbir işte çalışmazlar bundan dolayı da düşünürler hep keşke çalışabilseydim diye (Ö15). Diğer bir öğrenci ruhsal hastalığa sahip bireylere iş verilmediğini "Ruhsal hastalığa sahip bireylere iş verilmemektedir. İş verenler bu kişileri istememektedir" olarak ifade etmiştir. (Ö6).

\section{•Hastalığın İçselleştirilmesi}

Öğrencilerin ruhsal hastalığa sahip bireylerin hastalığı içselleştirdiklerini ifade etmiştir. Bir öğrencinin ifadesi "Ruhsal hastalığa sahip bireyler hastalıklarını 
içselleştirirler ve hayata küserler" şeklindedir. (Ö12).

\section{•Öz kıyım (İntihar)}

Öğrenciler ruhsal hastalığa sahip bireylerin öz kıyım girișimde bulunduklarını belirtmiştir. Bir öğrencinin ifadesi şu şekilde olmuştur: "Ruhsal hastalığa sahip bireylere yaklaşım çok farklı olur ve çok zorlanırlar kendilerini toplumdan dişlarlar toplum da onları dişlar ve bunun sonucunda intihar olur" (Ö20).

\section{Tema 2- İletişim}

Üç alt temadan oluşmaktadır.

\section{•Etkili İletişim Kuramama}

Öğrenciler ruhsal hastalı̆̆a sahip bireylerin etkili iletişim kuramadıklarını ifade etmiştir. Bir öğrencinin ifadesi "Ruhsal hastalığa sahip bireyler iletişim kurmakta zorlanırlar daha doğrusu etkili iletişim kuramazlar" dır. Ruhsal hastalığa sahip bireyler genellikle kısıtlı iletişim kurarlar ve çevresiyle çok fazla iletişime geçmezler" (Ö22).

\section{•Düşünme Sürecinde Bozulma}

Öğrenciler ruhsal hastalığa sahip bireylerin düşünme sürecinde bozulma olduğunu belirtmiştir. Bir öğrencinin ifadesi "Ruhsal hastalığa sahip bireylerin düşünme sürecinde bozulma görülebilir” dir. (Ö6).

\section{-Aile İlișkilerinde Bozulma}

Öğrenciler ruhsal hastalığa sahip bireylerin aile ilişkilerinde bozulmalar olduğunu ifade etmiştir. Bir öğrencinin ifadesi "Ruhsal hastalık aile içi ilişskilerini etkileyebilir ve bozulmalara yol açabilir"dir şeklinde olmuştur. (Ö23).

\section{Tema 3- Duygular}

Altı alt temadan oluşmaktadır.

\section{-Anksiyete}

Öğrenciler ruhsal hastalığa sahip olmanın bireyde anksiyeteye yol açabileceğini ifade etmiştir. Bir öğrenci şu şekilde belirtmiştir: "Ruhsal hastalığa sahip bireyler diğer insanlar gibi davranamadıklarını düşünüp eksiklik yaşayıp anksiyete yaşarlar (Ö11).

\section{-Mutsuzluk}

Öğrenciler ruhsal hastalığa sahip bireylerin mutsuzluk yaşadıklarını ifade etmiştir. Bir öğrencinin ifadesi "Ruhsal hastalığa sahip bireyler diğer insanlar gibi davranamadıklarını düşünüp eksiklik yaşayıp anksiyete yaşarlar ve mutsuz olurlar"şeklindedir. (Ö11).

\section{-Yalnızlık}

Öğrencilerden biri ruhsal hastalığa sahip bireylerin yalnızlık yaşadığını belirtmiştir. Öğrenci şu şekilde ifade etmiştir: "Ruhsal hastalığa sahip bireyler yaşadıkları damgalanmadan dolayı yalnızlığa sürüklenir"' (Ö21).

\section{•Öfke}

Öğrencilerden biri ruhsal hastalığa sahip bireylerin agresif olabileceğini şiddet eğilimlerinin olabileceğini ve öfkeli olabileceklerini ifade etmiştir. Öğrencinin ifadesi "Ruhsal hastalığa sahip bireyler agresif olabiliyorlar şiddet eğiliminde olup öfkeli olabilirler" şeklinde olmuştur (Ö20)

\section{Tema 4- Stigma Kırılmalı}

Dört alt temadan oluşmaktadır.

\section{-Topluma Kazandırabilmek}

Öğrenciler ruhsal hastalığa sahip bireylerin topluma kazandirılmaları gerektiğini ifade etmiştir. Bir öğrencinin ifadesi "Ruhsal hastalığa sahip bireylerin topluma kazandırılması gereken kişiler olduğunu düşünüyorum. Kesinlikle kazandırılmaları gerekiyor" şeklinde olmuştur.(Ö11).

\section{-Birey Olarak Kabullenmek}

Öğrenciler ruhsal hastalığa sahip bireylerin birey olarak kabullenilmeleri gerektiğini belirtmiştir. Bir öğrencinin ifadesi "Ruhsal hastalığa sahip bireyler birey olarak kabullenildikleri zaman sevgi gösterildikleri zaman ve değer verildikleri normal birey olabilirler" dir.(Ö11).

-Değer Vermek 
Öğrenciler ruhsal hastalığa sahip bireylere değer verilmesi gerektiğini ifade etmiştir. Bir öğrenci şu şekilde belirtmiştir. "Ruhsal hastalığa sahip bireyler birey olarak kabullenildikleri zaman sevgi gösterildikleri zaman ve değer verildikleri normal birey olabilirler" (Ö11).

\section{-Ön Yargıların Azaltılması}

Öğrenciler ruhsal hastalığa sahip bireyler konusunda önyargıların azaltılması gerektiğini ifade etmiştir. Bir öğrencinin ifadesi șu șekilde olmuştur. "Ruhsal hastalığa sahip bireylere ön yargılı yaklaşmazsak ya da en azından azaltırsak onları damgalamazsak onlar da bu toplumda yaşar" (Ö11)

Tablo 4'de öğrencilerin branș olarak psikiyatri hemşireliği ile ilgili düşüncelerine yönelik kod ve temalar yer almaktadır.

Tablo 4. Hemşirelik Son Sınıf Öğrencilerinin Branş Olarak Psikiyatri Hemşireliği ile İlgili Görüşleri

\begin{tabular}{llll}
\hline Tema & Kod & Katılımcı & f \\
\hline Zor bir & Hastalardan & Ö5, Ö8, & 4 \\
alan & korkma & Ö15, Ö23 & \\
& Özel bir alan & Ö1, Ö10, & 3 \\
& $\begin{array}{l}\text { Ö19 } \\
\text { Yipratıc1 }\end{array}$ & Ö12, Ö16 & 2 \\
& $\begin{array}{l}\text { Sabır } \\
\text { gerektiren }\end{array}$ & Ö16 & 1 \\
\hline Iletişim & Etkili iletişim & Ö2, Ö7, & 3 \\
temelli & $\begin{array}{l}\text { kurma } \\
\text { Terapötik ilişki } \\
\text { kurma }\end{array}$ & Ö23 & 1 \\
& $\begin{array}{l} \\
\text { Özen }\end{array}$ & Ö16 & 1 \\
& gerektiren & Ö11 & 1 \\
Toplam & Empati & & $\mathbf{1 6}$ \\
\hline
\end{tabular}

\section{Kategori 3. "Branş Olarak Psikiyatri} Hemşireliği ile İlgili Görüşler"

\section{Tema 1-Zor Bir Alan}

Dört alt temadan oluşmaktadır.

\section{-Hastalardan Korkma}

Öğrencilerin bazıları ruhsal hastalığa sahip bireylerden korktuklarını ve yapamayacaklarını ifade ederken bazıları da korkmadığını psikiyatri hemşireliğini yapabileceklerini ifade etmiştir. Meslek olarak psikiyatri hemşireliğini yapamayacağını düşünen ve ruhsal hastalığa sahip bireylerden korkan bir öğrencinin ifadesi "Ruhsal hastalığa sahip bireyleri tehlikeli buluyorum bana saldıracaklarını düşünüyorum ve korkuyorum" dur.(Ö23).

\section{-Özel Bir Alan}

Öğrenciler psikiyatri hemşireliğinin diğer alanlardan farklı bir alan olduğunu belirtmiştir. Bir öğrenci şu şekilde belirtmiştir: "Psikiyatri hemşireliği diğer alanlar gibi değil çok farklı ve özel bir alan olduğunu düşünüyorum. Bir cerrahi ya da dahiliye hemşireliği gibi değil çok daha farklı ve ilginç bir alan"(Ö1).

\section{-Yıpratici}

Öğrenciler meslek olarak psikiyatri hemşireliğinin yıpratıcı olduğunu ifade etmiştir. Bir öğrencinin ifadesi "Psikiyatri hemşireliğinin diğer alanlardan yıpratıcı olduğunu düşünüyorum" dur.(Ö12).

\section{-Sabır Gerektiren}

Öğrencilerden biri meslek olarak psikiyatri hemşireliğinin sabır gerektiren bir alan olduğunu belirtmiştir. Öğrencinin ifadesi "Psikiyatri hemşireliği sabır gerektiren bir alandır" şeklinde olmuştur. (Ö16).

\section{Tema 2-İletişim Temelli}

Dört alt temadan oluşmaktadır.

\section{-Terapötik İlişki Kurma}

Öğrencilerden biri psikiyatri hemşireliğinde terapötik ilişki gerektiğini ifade etmiştir. Öğrenci "Psikiyatri hemşireliği terapötik ilişki gerektirir bu olmazsa etkili bakım olmaz" şeklinde ifade etmiştir. (Ö2).

\section{-Empati}

Öğrencilerden biri psikiyatri hemşireliğinin empati gerektiren bir meslek olduğunu belirtmiştir. Öğrencinin ifadesi "Psikiyatri hemşireliği empati kurmayı gerektirir" dir. (Ö11).

\section{•Etkili İletişim Kurma}

Öğrenciler meslek olarak psikiyatri hemşireliğinde etkili iletişim kurmanın gerektiğini ifade etmiştir. Bir öğrencinin ifadesi "Psikiyatri hemşireliğinde hastalarla 
etkili iletişim kurmak gerekir yoksa bu meslek zor yap1lır" dir. (Ö2).

\section{•Özen Gerektiren}

Katılımcilardan biri meslek olarak psikiyatri hemşireliğinin özen gerektiren bir alan olduğunu ifade etmiştir. Öğrencinin ifadesi "Psikiyatri hemşireliği özen gerektiren bir alandır" şeklinde olmuştur. (Ö16).

Tablo 5'da öğrencilerin psikiyatri kliniğinde çalışmaya ilişkin görüşlerine yönelik kod ve temalar yer almaktadır.

Tablo 5. Hemşirelik Son Sınıf Öğrencilerinin Psikiyatri Kliniğinde Çalışmaya İlişskin Görüsşleri

\begin{tabular}{|c|c|c|c|}
\hline Tema & Kod & Katılımcı & f \\
\hline \multirow[t]{3}{*}{ Çalışabilirim } & Özel bir alan & $\begin{array}{l}\text { Ö1, Ö3, Ö10, } \\
\text { Ö11, Ö18, } \\
\text { Ö22, Ö23 }\end{array}$ & 7 \\
\hline & $\begin{array}{l}\text { Yardım } \\
\text { etmek için }\end{array}$ & $\begin{array}{l}\text { Ö4, Ö10, Ö11, } \\
\text { Ö14, Ö18, } \\
\text { Ö22 }\end{array}$ & 6 \\
\hline & $\begin{array}{l}\text { Doyum veren } \\
\text { bir alan }\end{array}$ & $\begin{array}{l}\text { Ö4, Ö16, } \\
\text { Ö18, Ö22, } \\
\text { Ö23 }\end{array}$ & 5 \\
\hline \multirow[t]{3}{*}{ Çalışamam } & $\begin{array}{l}\text { Korku/ } \\
\text { Anksiyete }\end{array}$ & $\begin{array}{l}\text { Ö1, Ö2, Ö6, } \\
\text { Ö8, Ö12, Ö15, } \\
\text { Ö17 }\end{array}$ & 7 \\
\hline & Etkilenme & Ö6, Ö9, Ö20 & 3 \\
\hline & $\begin{array}{l}\text { İletişim } \\
\text { kuramama }\end{array}$ & Ö17 & 1 \\
\hline Toplam & & & 29 \\
\hline
\end{tabular}

Kategori 4. Psikiyatri Kliniğinde Çalışma İle İlgili Görüşler"

\section{Tema 1- Çalışabilirim}

Üç alt temadan oluşmaktadır.

\section{- Özel Bir Alan}

Öğrenciler psikiyatri hemşireliğinde çalışmanın diğer alanlardan farklı bir alan olduğunu belirtmiştir. Bir öğrencinin ifadesi "Psikiyatri hemşireliği diğer alanlar gibi değil çok farklı ve özel bir alan olduğunu düşünüyorum. Bir cerrahi ya da dahiliye hemşireliği gibi değil çok daha farklı ve ilginç bir alan" dır.(Ö1)

Başka bir öğrenci psikiyatri hemşireliğinin özel bir alan olduğunu şu şekilde belirtmiştir: "Psikiyatri hemşireliği kesinlikle özel bir alan sevmeden asla yapılamaz ve ben bir dahiliyeden bir cerrahiden bir yoğun bakımdan çok faklı olduğunu düşünüyorum" (Ö3)

\section{-Doyum Veren Bir Alan}

Öğrenciler psikiyatri hemşireliğinde çalışmanın doyum verici olduğunu düşünmektedir. Bir öğrencinin ifadesi "Psikiyatri hastalarıyla zaman geçirmek benim için çok güzel ve doyum verici............."dir. (Ö4).

\section{-Yardım Etmek İçin}

Öğrenciler psikiyatri hastalarına yardım etmenin güzel bir duygu olduğunu ve onları yalnızlaştırmamak gerektiğini belirtmişlerdir. Öğrencilerin ifadeleri şöyledir: "Öğrenciler psikiyatri hemşireliğinde bireylere yardım etmek çok güzel onların iyileştiğini görmek güzel....." (Ö4). "Ruhsal hastalığa sahip bireyleri yalnızlaştırmamak gerekir ve bunun için de psikiyatriyi seçmeyi isterdim" (Ö14)

\section{Tema 2-Çalışamam}

Üç alt temadan oluşmaktadır.

\section{-Korku/Anksiyete}

Öğrenciler psikiyatri kliniğinde çalışmaktan korktuklarını ve anksiyete yaşadıklarını ifade etmiştir. Öğrencilerin ifadeleri "Psikiyatri hemşireliği benim kesinlikle yapabileceğim bir alan değil çok korkuyorum........... Korktuğum için de zorlanacağımı düşünüyorum........." (Ö12). "Psikiyatri kliniğginde çalışırsam anksiyete yaşayabilirim” şeklinde olmuştur. (Ö6).

\section{-Etkilenme}

Öğrenciler psikiyatri kliniğinde çalıştıkları takdirde etkilenebileceklerini ifade etmiştir. Bir öğrencinin ifadesi "Psikiyatri kliğinde çalışırsam etkilenebilirim ve hastalara sempati duyabilirim bu yüzden psikiyatri kliniğinde çalışmayı düşünmüyorum" şeklinde olmuştur.(Ö20).

\section{-İletişim Kuramama}

Öğrenciler psikiyatri kliniğinde bireylerle iletişim kuramayabileceğini bu yüzden çalışamayacağını ifade etmiştir: "Psikiyatri kliniğinde hastalarla iletişim kuramayabilirim bu yüzden çalışamayabilirim" (Ö17). 
Çalışmamız hemşirelik son sınıf öğrencilerinin mezuniyet sonrası psikiyatri kliniğinde çalışmaya ilişskin görüşlerinin belirlenmesi amacıyla yapılmıştır.

Hemșirelik son sınıf öğrencilerinin ruhsal hastalık algısı kavramına ilişkin kategorisine baktığımızda; nedenler (çocukluk travmaları, travmatik olaylar ve ailedeki sevgisizlik), stigma (fiziksel hastalık gibi değil, dışlama ve tehlikeli) ve iletişim sorunları (kendi iç dünyasına çekilme, gerçeği algılayamama, kendini ifade etmede zorlanma) temaları yer almaktadır. Alpan ve arkadaşlarının (2018) yaptıkları "Sağlık Bilimleri Fakültesi Öğrencilerinin Şizofreni Hastalığına Karşı Tutumları" başlıklı çalışmada şizofreni hastalığının etiyolojisine ilişkin, öğrencilerin görüssleri incelendiğinde; öğrencilerin, yarıya yakını şizofreninin kişilik yapısının zayıf olmasından ve yarısının yaşadığı sosyal sorunlardan kaynaklandığına katıldığ belirlenmiştir. ${ }^{16}$

Öğrencilerin "ruhsal hastalığ olan bireye ilişkin görüşler" kategorisi; stigma (toplumda ötekileştirilme, sosyal işlevsellikte bozulma, çalıșma hayatında yer alamama, hastalığın içselleştirilmesi, öz kıyım), iletişim (etkili iletişim kuramama, düşünme sürecinde bozulma, aile ilişkilerinde bozulma), duygular (anksiyete, mutsuzluk, yalnızlık, öfke), stigma kırılmalı (topluma kazandırabilmek, birey olarak kabullenmek, değer vermek, ön yargiların azaltılması) temalarından oluşmaktadır. Ruhsal sağlığa sahip bireylerle ilgili düşüncelere yönelik temalarda anksiyete teması ile öğrenciler özellikle şizofrenili bireylerle iletişim kurma ve ona bakım vermekte zorluk çektiklerini belirtmişlerdir. $\mathrm{Bu}$ durum, öğrencilerin genel olarak psikiyatri hastalarına yönelik ön yargılarından kaynaklanmış olabilir. Çalışmamıza benzer olarak Danacı ve arkadaşlarının (2016) "Tıp Eğitiminin Sizofreniye Yönelik Tutumlar Üzerine Etkisi; 5 Yıllık İzlem Çalışması" adlı çalışmada 1. sınıfta \%45,3'ü $(n=48), 5$. sınıfta $\% 23^{\prime} \ddot{\mathrm{u}} \quad(\mathrm{n}=23)$ şizofreni hastalarının saldırgan olduğunu ifade etmiştir. ${ }^{17}$

Hemşirelik son sınıf öğrencilerinin meslek olarak psikiyatri hemşireliği ile ilgili görüşler kategorisi içerik (zor bir alan, hastalardan korkma, etkili iletişim kurma, özel bir alan, özen gerektiren ve yıpratıc1), iletişim temelli (terapötik ilișki kurma, sabır gerektiren ve empati kurmak) temalarından oluşmaktadır. Yildız (2019) yaptığ 1 "What Do Nursing Students Tell Us About Their Communication With People With Mental Illness? A Qualitative Study" adlı 26 öğrenciyle yaptığ psikiyatri kliniğindeki hastalarla duygu ve düşüncelerinden dolayı kısıtlama yaşadıkları için etkili iletişim kuramadıklarını belirttiği saptanmıştır. ${ }^{18}$

Happel ve Gaskın (2013) "The attitudes of undergraduate nursing students towards mental health nursing: A systematic review" adlı araştırmada hemşirelik öğrencilerinin ruh sağlığ1 ve hastalıkları hemşireliği en az tercih edilen kariyer seçeneği olarak gördükleri belirtilmiştir. ${ }^{9}$ Avustralya, ABD, Singapur, Orta Doğu, İngiltere ve Hırvatistan'da yapılan araştırmalar, ruh sağlığı ve hastalıkları hemşireliğinin genellikle kariyer tercihi olarak popüler olmadığını göstermektedir. ${ }^{20}$

Katılımcıların psikiyatri kliniğinde çalışma ile ilgili görüşler" kategorisi ise; çalışabilirim (özel bir alan, doyum veren bir alan, yardım etmek için), çalışamam (korku/anksiyete, etkilenme ve iletişim kuramama) temalarından oluşmaktadır. Happel ve Gaskın (2013) "The Attitudes Of Undergraduate Nursing Students Towards Mental Health Nursing: A Systematic Review" adlı araştırmasında hemşirelik ögrencilerinin psikiyatri kliniklerini öğrencilerin anksiyeteli ortamlar olarak gördükleri belirlenmiştir. ${ }^{19}$

Altıok ve Kızılkaya'nın (2017) yaptıkları "Öğrencilerin ruh sağlığı ve hastalıkları hemşireliği dersinin klinik uygulamasına ilişkin yeterlilik algıları" başlıklı çalışmasında öğrencilerin klinik ortamın kapalı olması sebebiyle korku yaşama, klinik uygulama süresinin yetersiz olması ve devlet hastanelerinin sistemden kaynaklanan sorunları nedeniyle kendilerini yetersiz hisssettikleri saptanmıştır. ${ }^{21}$ 


\section{SONUÇ VE ÖNERİLER}

Çalışmamızda hemşirelik son sınıf öğrencilerinin mezuniyet sonrası psikiyatri kliniğinde çalışma ile ilgili görüşlerinin belirlenmesi amacıyla yapılan çalışmadan şu sonuçlar elde edilmiştir. Hemşirelik son sınıf öğrencileri; ruhsal hastalığın fiziksel hastalıktan farklı ve tehlikeli olduğunu, ruhsal hastalığa sahip bireylerin şiddet eğilimi olduğunu, stigmaya maruz kalarak toplumdan dışlandıklarını ve topluma kazandırılmaları gerektiğini ifade etmişlerdir. Ruhsal hastalık ve ruhsal hastalığı olan bireye ilişkin bu görüşlere sahip olan öğrenciler, psikiyatri hemşireliğini sabır gerektiren, yıpratıcı ve zor bir alan olarak değerlendirmektedirler. Çalışmaya katılan öğrencilerin yarıdan fazlası psikiyatri hemşireliğini özel, doyum veren bir alan olarak gördükleri ve ruhsal hastalığa sahip bireylere yardım etmek istedikleri için psikiyatride çalışabileceklerini belirtmişlerdir. Diğer öğrenciler ise bu bireylere ilișkin korku/anksiyete hissettikleri, etkilenebileceklerini ve iletişim kuramayacaklarını düşündükleri için mezuniyet sonrası psikiyatri kliniğinde çalışamayacaklarını ifade etmişlerdir. $\mathrm{Bu}$ sonuçlar doğrultusunda; hemşirelik lisans programındaki ruh sağlığı ve hastalıkları hemşireliği dersinin öğrencilerin iletişim becerilerini geliştirme, ruhsal hastalığa sahip bireylere ilişkin hissedilen korku/anksiyete ile baş etmeyi destekleme ve stigmanın kırılmas1 yönünde planlanması önerilmektedir.

KAYNAKLAR

1. Öztürk, S. (2018). Psikiyatri Kliniklerindeki Sağlık Çalışanlarının ve Hastaların Terapötik Ortam Algıları (Yüksek Lisans Tezi). Hacettepe Üniversitesi, Sağlık Bilimleri Enstitüsü,Ankara.

2. Özbaş, D., Buzlu, S. (2011). Hemşirelik Öğrencilerinin Psikiyatri Hemsireliği Dersine ve Psikiyatri Hemsiresinin Rollerine İlişkin Düşünceleri. Anadolu Hemşirelik ve Sağlık Bilimleri Dergisi.14 (1), 40-31.

3. Sahin, G., Koptaş, O. S., \& Buzlu, S. (2019). Standardize Hasta Kullanılarak Yapılan Bir Ruh Sağlığ ve Psikiyatri Hemsireliğ̣i Klinik Simülasyon Deneyimi. ACU Sağlık Bil $\begin{array}{llll}\text { Derg } & 2019 ; & 10 & \text { (3),486-492. }\end{array}$ https://doi.org/10.31067/0.2019.181.

4. Happell, B. (1999). When I grow up I want to be a...? Where Undergraduate Student Want To Work After Graduation, Journal of Advanced Nursing, 29 (2), 499-505

5. Öztürk, A., Kaçan Softa, H., \& Karaahmetoğlu Ulaş, G. (2015). Kastamonu Üniversitesi'nde Öğrenim Gören Hemșirelik Öğrencilerinin Ruhsal Hastalıklara Karșı İnançları ve Psikiyatri Hemşireliği Dersinin Etkisi, 4,146-166.

6. Surgenor, L.J., Dunn, J. H. (2005). "Nursing Student Attitudes to Psychiatric Nursing and Psychiatric Disorders in New Zealand." International Journal Of Mental Health Nursing, 14 (2), 103-8.

7. Arnold, S.A., Deans, C., Munday, J. (2004). "University and Service Sector Collaboration for Undergraduate Psychiatric Nursing Education.” International Journal of Mental Health Nursing, 13, (1) 61-6.

8. Öz, F. İnci, F. (2005). "The effect Of Mental Health And Psychiatric Nursing Course On Attitudes Of Nursing Students Towards İndividual Swith Mental Health Problems." J,Crisis, 17 (2), 39-47.

9. Kayahan, M. (2009). "Hemşirelik Öğrencilerinin Şizofreniye Karşı Tutumları ve Psikiyatri Eğitiminin Etkisi." Harran Üniversitesi Tıp Fakültesi Dergisi, 6 (1), 27-34.
10. Yildırım, A. Simșek, H. (2011). Sosyal Bilimlerinde Nitel Arastirma Yöntemleri (8. baskı). Ankara: Seçkin Yayinevi.

11. Polit, D.F.,\&Beck, C.T. (2012). "Nursing Research: Generating And Assessing Evidence For Nursing Practice." Ninth Edition. Philadelphia: Wolters Kluwer Health/Lippincott Williams \& Wilkins.

12. Yıldırım, A. Şimşek, H. (2009). Sosyal Bilimlerde Nitel Araştırma Yöntemleri. Ankara: Seçkin Yayınevi.

13. Burns, N. Grove, S. K. (2007). Understanding Nursing Research: Building an Evidence-Based Practice. (4th ed.,pp.), 2 (3), 134-163). China: Saunders.

14. Erdoğan, S. Nahcivan, N. Esin, N. Coşansu, G. Seçginli, S (2014). Hemşirelikte Araştırma, İstanbul: Nobel Tıp Kitapevi.

15. Özdemir, M. (2010). Nitel Veri Analizi: Sosyal Bilimlerde Yöntembilim Sorunsalı Üzerine Bir Çalıșma. Eskişehir Osmangazi Üniversitesi Sosyal Bilimler Dergisi, 11 (1) ,323$343 . \quad$ Retrievedfrom https://dergipark.org.tr/tr/pub/ogusbd/issue/10997/131612

16.Alpan, A. Kocamanoğlu, E. Yüce, F. Akçakmak, G. Günbal, M Așık, E. Albayrak, S. (2018). Sağlık Bilimleri Fakültesi Öğrencilerinin Şizofreni Hastalığına Karşı Tutumları. Kirikkale Univ Tip Fak Derg., 20 (1), 8-17.

17. Danacı, A. E., Balıkçı, K., Aydın, O., Cengisiz, C., \& Uykur, A. B. (2016). "Tıp Eğitiminin Şizofreniye Yönelik Tutumlar Üzerine Etkisi; 5 Yıllık İzlem Çalıșması.’Turk Psikiyatri Dergisi, 27 (3), 176-84.

18. Yıldı, E. (2019). "What Do Nursing Students Tell Us About Their Communication With People With Mental Illness? A Qualitative Study." Journal of the American Psychiatric Nurses Association, 1078390319892311.

19. Happel, B. \& Gaskin, CJ. (2013). "The Atti-Tudes Of Undergraduate Nursing Stu-Dents Towards Mental Health Nursing:A Systematic Review." Journal of Clinical Nursing $22(1-2), 148-158$ 
20. Bingham, H., \& O'Brien, A. J. (2018). "Educational Intervention To Decrease Stigmatizing Attitudes Of Undergraduate Nurses Towards People With Mental İllness.” International Journal of Mental Health Nursing, 27 (1), 311319 .
21. Altıok, H. Ö., \& Kızılkaya, M. (2019). “Öğrencilerin Ruh Sağlığı ve Hastalıkları Hemşireliği Dersinin Klinik Uygulamasına İlișkin Yeterlilik Algıları.” Anadolu Hemşirelik ve Sağlık Bilimleri Dergisi, 20 (1), 22-33. 